\title{
KONSEPSI PENDIDIKAN KASIH SAYANG DAN KONTRIBUSINYA TERHADAP BANGUNAN PSIKOLOGI PENDIDIKAN ISLAM
}

\author{
Azam Syukur Rahmatullah \\ (Dosen Pascasarjana IAINU Kebumen)
}

\begin{abstract}
This article talking about love and affection education concepts is it has a great function in education world, is so great for student/pupils. With love and affection education will brings students/pupils to enjoyable in life, peaceful in heart, and have a certain attitude and all that from the heart. The aims application love and affection education is to clear juvenile delinquency.
\end{abstract}

\section{A. Pendahuluan}

Kasih sayang merupakan modal besar dalam mendidik remaja, dengan kasih sayang inilah akan menghantarkan kunci "kesuksesan remaja" dalam berbagai bidang yang selaras dengan talenta-nya. Dengan kasih sayang pula akan melahirkan remaja-remaja yang kreatif, inovatif unggulan dan berprestasi.

Pendidikan berbasis kasih sayang idealnya dikembangkan dan dibudayakan oleh berbagai kalangan; keluarga, sekolah, masyarakat dan institusi-institusi kelembagaan lainnya. Sebab pendidikan sejenis ini lebih banyak berdampak positif terhadap remaja dan lebih mendorong remaja pada perilaku yang positif pula.

Allport menyatakan bahwa penerapan pendidikan kasih sayang berupa ajaran hubungan diri yang hangat dengan orang lain merupakan salah satu bentuk dari kematangan dalam kepribadian. ${ }^{1}$ Karenanya menurut penulis tidak salah jika pendidikan

${ }^{1}$ DuaneSchualtz, Psikologi Pertumbuban Model-model Kepribadian Sebat, penerj. Yustinus, (Yogyakarta : PT Kanisius, 1991) hlm. 32. Menurut Allport ada tujuh kriteria kepribadian yang matang di antaranya : Pertama, perluasan perasaan diri, Kedua, hubungan yang penuh kehangatan dan kasih sayang dengan orang lain, Ketiga, keamanan emosional, Keempat, persepsi realistis, Kelima, ketrampilan-ketrampilan dan tugas-tugas, Keenam, pemahaman diri dan Ketujuh, filsafat hidup yang mempersatukan. 
kasih sayang menjadi "tujuan" dan "tumpuan" berbagai kalangan meski baru sebatas "harapan" (expectasi) dan belum sempurna dalam tataran aktualisasi. Sebagai bukti masih banyak orang tua yang lebih mengedepankan kekerasan terhadap remaja, atau guru yang kurang memperhatikan keluh kesah peserta didik, atau pula guru yang lebih memilih hukuman dengan kekerasan daripada sentuhan qalb.

Muhammad Anis menyatakan bahwa sebenarnya Allah telah mengajarkan kepada umat manusia untuk senantiasa memiliki sifat rahmah yakni sifat yang penuh kasih sayang terhadap makhlukmakhluk sesama manusia maupun selain manusia, sebab yang menyayangi akan selalu memberikan kebaikan kepada yang disayangi. ${ }^{2}$ Bukti kebesaran rasa kasih sayang illabi kepada makhluknya tercermin jelas pada hadi Rasulullah, dimana cerminan ini dapat dijadikan tauladan mulia bagi masyarakat sosial agar selalu mentradisikan pendidikan berbasis kasih sayang terhadap siapapun. Rasulullah SAW bersabda :

Dari Aisyah r.a bahwasanya Nabi Saw bersabda : "Sesungguhnya Allah itu lunak dan menyukai kelunakan. Allah memberi karena kelunakan apa yang tidak Ia berikan karena kekerasan, dan yang tidak Ia berikan karena yang lain. (HR. Muslim)

Terlihat pada hadi di atas, Allah mengajarkan untuk mengembangkan kecerdasan interpersonal dalam masyarakat sosial dengan saling menyayangi, bersikap lunak tidak keras terhadap sesama makhluk tidak terkecuali binatang sekalipun. Dalam hal ini terlihat Allah menyayangi semua makhluknya dalam bentuk dan ragam apapun. Hal ini menjadi pelajaran besar bagi manusia sebagai makhluk yang berakal untuk tidak hanya mengembangkan rasa kasih sayang, sikap lunak dan santun kepada mereka-mereka yang sehat jiwa dan sehat perilakunya saja dan memarginakan kaum-kaum yang memiliki gangguan mental atau gangguan nafsaniah, tetapi mengembangkan kasih sayang pula kepada mereka-mereka yang memiliki problem-problem diri; penyimpangan perilaku termasuk di dalamnya kenakalan kaum remaja.

${ }^{2}$ Muhammad Anis, Quantum al-Fatihah ; Membangun Konsep Pendidikan Berasis Surah al-Fatihah, (Yogyakarta : Pedagogia, 2010) hlm. 53-55. 


\section{B. Memaknai Pendidikan Kasih Sayang}

Istilah pendidikan kasih sayang merupakan penggabungan dari dua suku kata yakni "pendidikan" dan "kasih sayang", yang keduanya memiliki kandungan makna berbeda. Keduanya akan digabungkan menjadi "pendidikan kasih sayang" dan memiliki makna berbeda pula.

Sehubungan dengan pendidikan itu sendiri, banyak para pakar yang mendefinisikan berbeda antara satu definisi dengan definisi lainnya. Menurut Noeng Muhajir pendidikan adalah upaya membantu proses pengembangan subyek didik. ${ }^{3}$ Menurut definisi ini pendidikan bukan hanya "konsep transfering of knowledge" tetapi lebih mendalam dan membawa peserta didik pada tahapan "kemandirian hidup" yang didampingi "kemuliaan akblak." Pada esensinya, pendidikan mengarahkan individu pada term besar yakni "perubahan" baik itu perubahan dilihat dari cara pandang, perubahan kedewasaan (maturity), perubahan tata bicara dan perubahan sikap.

Pernyataan penulis tersebut diperkuat dengan asumsi AlGhazali yang menyatakan pendidikan adalah suatu proses kegiatan yang memiliki sistem yang jelas guna melahirkan perubahanperubahan positif baik perubahan cara pandang atau pola pikir, perubahan mental, perubahan aksi atau tingkah laku manusia. ${ }^{4}$

Sesuai definisi Al-Ghazali, ada hal-hal yang "berubah" ketika seseorang berpendidikan; berubah cara pandang, yang lebih terbuka (open minded) terbuka wawasan, terbuka dalam memecahkan masalah (problem solving) terbuka pengetahuan baru. Berubah dalam hal mental, yang memiliki mental sehat, dan jauh dari kelemahan mental. Sedangkan perubahan lainnya perubahan tingkah laku yang dengan aturan-aturan syar'i, adat dan hukum positif.

Syed Hossein Nashr memberikan tambahan pandangan bahwa pendidikan harus bersifat menyeluruh(bolistik). ${ }^{5}$ Makna keseluruhan; pendidikan fisik, pendidikan jiwa, pendidikan intelektual, pendidikan moral, yang mampu membawa pada

${ }^{3}$ Noeng Muhajir, Ilmu Pendidikan dan Perubahan Sosial : Suatu Teori Pendidikan, edisi IV (Yogyakarta : Rake Sarasin, 1993) hlm. 17.

${ }^{4}$ Busyairi Madjidi, Konsep Pendidikan Para Filosof Muslim (Yogyakarta : al- Amin Press, 1997) hlm. 86.

${ }^{5}$ Syed Hosssein Nasr, Islam Tradisi di Tengah Kancah Dunia Modern, alih bahaas Luqman Hakim (Bandung: Pustaka, 1987) hlm. 125. 
tatanan perubahan yang diharapkan, sesuai pernyataan oleh Noeng Muhajir dan al-Gazali pada bagian awal.

Dengan demikian, dari semua definisi tersebut di atas dapat penulis verbalisasikan dalam sebuah definisi bahwa pendidikan adalah seluruh aktivitas atau upaya secara sadar yang dilakukan oleh pendidik kepada peserta didik, atau oleh orang tua, pembina dan pembimbing terhadap anak atau remaja bahkan kaum dewasa terhadap semua aspek perkembangan kepribadian baik jasmani maupun rohani, secara formal, informal maupun non-formal yang berjalan terus-menerus mencapai kebahagiaan dan nilai yang tinggi, baik nilai insāniyyah maupun lābiriyyah.

Hal di atas adalah pemaparan perihal pengertian pendidikan dan berikut akan dipaparkan pula pengertian kasih sayang yang mencakup pengertian secara bahasa dan istilah. Kasih sayang dalam bahasa Arab dikenal dengan istilah rahmab( ) atau rabmat berasal dari akar kata rahima-yarhamu- rabmah ( ), yang berarti mengasihi atau menaruh kasihan. ${ }^{6}$ Dalam kitab al-Munjid rabimayarhamu- rahmah memiliki makna رقّ له وشفق عليه وتعطف وغفر له yang berarti menaruh kasihan dan menyayangi dan mengasihani dan memaafkannya. ${ }^{7}$ Demikian pula jika dilihat pada kitab kamus alMunawwir Arab-Indonesia Terlengkap, makna rabima-yarhamu- rahmah adalah وقّ له dan menyayangi. "

Di dalam Wikipedia Kamus Ensiklopedia Bebas Bahasa Indonesia, kasih sayang dikenal sebagai afeksi yang diartikan semacam status kejiwaan yang disebabkan oleh pengaruh elesternal atau dapat diartikan hubungan antara dua orang atau lebih yang lebih dari sekedar rasa simpati atau persahabatan. ${ }^{9}$ Rasa simpati itu sendiri merupakan proses seseorang merasa tertarik terhadap pihak lain sehingga mampu mersakan apa yang dialami, dilakukan dan diderita orang lain. Adapun persahabatan merupakan penggambaran perilaku kerjasama dan saling mendukung antara dua atau lebih entitas sosial. Sedangkan dalam Kamus Besar

${ }^{6}$ Mahmud Yunus, Kamus Arab-Indonesia (Jakarta : Hidakarya Agung, 1990) hlm. 139.

7 Al-Munjid, (Beirut :Maktabah al-Syarkiyah, 1986) hlm. 253.

${ }^{8}$ Ahmad Warson. Munawwir, Kamus al-Munawnir Arab-Indonesia Terlengkap (Surabaya, Pustaka Progressif, 2002) hlm. 483.

${ }^{9}$ Afeksi (Kasih SAyang),Wikipedia Ensiklopedia Bebas Bahasa Indonesia, http://id.wikipedia .org/wiki/afeksi 
Bahasa Indonesia kasih sayang bermakna memiliki perasaan cinta kasih dan belas kasihan. ${ }^{10}$

Adapun di dalam Al-Qur'ān dalam berbagai bentuknya, kata kasih sayang atau يَزْحَمُ $\quad$ terulang sebanyak 338 kali. Yakni, di dalam bentuk fi'l mâdhi disebut 8 kali, fi'l mudhâri'15 kali, dan fi'l amr 5 kali. Selebihnya disebut di dalam bentuk ism dengan berbagai bentuknya. Kata rahmah sendiri disebut sebanyak 145 kali. 11

Ibnu Faris menyebutkan bahwa kata yang terdiri dari fonem $r a, b a$, dan mim, pada dasarnya menunjuk kepada arti "kelembutan hati", "belas kasih", dan "kehalusan". ${ }^{12}$ Dari akar kata ini lahir kata rabima ( ), yang memiliki arti "ikatan darah, persaudaraan, atau hubungan kerabat." Penamaan rabim pada pemaknaan perempuan karena darinya terlahir remaja yang akan menerima limpahan kasih sayang dan kelembutan hati.

Al-Asfahani menyebutkan bahwa rahmah adalah belas kasih yang menuntut kebaikan kepada yang dirahmati. Kata ini kadangkadang dipakai dengan arti ar-riqqat al-mujarradab (= belas kasih semata-mata) dan terkadang dipakai dengan arti al-Ihsân al-mujarrad dûn ar-riqqah (= kebaikan sematamata tanpa belas kasih). ${ }^{13}$ Misalnya, jika kata rabmah disandarkan kepada Allah, maka carti yang dimaksud tidak lain adalah "kebaikan semata-mata." Sebaliknya, jika disandarkan kepada manusia, maka arti yang dimaksud adalah simpati semata. Oleh karena itu, lanjut Al-Asfahani, diriwayatkan bahwa rahmah yang datangnya dari Allah adalah in'âm( = karunia atau anugerah), dan ifdhâl ( = kelebihan) dan yang datangnya dari manusia adalah riqqab( = belas kasih).

Adapun pengertian kasih sayang jika dilihat dari sisi istilabi mengandung maka Muhammad Anis berpendapat bahwa kasih

${ }^{10}$ Departemen Pendidikan Nasional, Kamus Besar Bahasa Indonesia, Jakarta : Balai Pustaka, 2002) Edisi Ketiga., hlm. 512.

${ }^{11}$ N.A Baiquni dkk., Indeks al-Qur'an Cara Mencari ayat Al-Qur'an, (Surabaya : Penerbit Arloka, 1996)

${ }^{12}$ Dapat dilihat pada artikel Rahmah (Kasih sayang), http://www.psq .or.id / ensiklo pedia_detai 1 .asp? mnid =34\&id=107

${ }^{13}$ Dapat dilihat di artikel Mustarak dalam Al-Qur'an, tema : Rahmah (Kasih Sayang) http:/ / www.akhirzaman.info/islam/miscellaneous/1656-musytarak-dalam-alquran.html 
sayang diartikan sebagai perbuatan dari seseorang yang memberikan kenyamanan, kesenangan, keharmonisan dan rasa penghargaan kepada orang lain. ${ }^{14}$ Masih menurut Anis kasih sayang merupakan salah satu kebutuhan dasar (basic need) setiap manusia. Karenanya memang kasih sayang wajib disebarkan dan diluaskan. Sebagaimana Rasulullah diutus Allah untuk menyebarkan rabmah atau kasih sayang bagi seluruh alam.

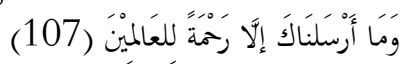

Artinya : Dan Tiadalah Kami mengutus kamu, melainkan untuk. (menjadi) rahmat bagi semesta alam.

Sejalan dengan pernyataan Muhammad Anis di atas, kenyamanan, keamanan, keharmonisan diwujudkan dengan tidak adanya unsur pemukulan, kekerasan, penghinaan dan umpatan. Hal ini dinyatakan pula oleh Jaudah Muhammad Awwad pun memberikan definisi kasih sayang ini yang menurutnya adalah suatu hal yang di dalamnya tidak ada unsur kekerasan, umpatan, pemukulan baik terhadap orang lain apalagi terhadap remaja. ${ }^{15}$ Sedangkan Allen N. Mendler memberikan pandangannya bahwa yang dinamakan kasih sayang adalah kedekatan emosional terhadap orang lain dan ada di dalamnya unsur mengasihi. ${ }^{16}$

Penulis berasumsi bahwa pernyataan Muhammad Anis dan Jaudah Muhammad Awwad merupakan bentuk atau wujud dari afeksi yang dinyatakan oleh satu pihak ke pihak lain, atau satu personal ke personal lain, untuk menjadikan pihak lain merasakan kedamaian individual dan sosial. Sehingga pada akhirnya, pihak yang merasakan dampak positif dari perilaku afeksi tersebut, akan mengembangkan kepekaan intrapersonal dan interpersonal.

Berbeda dengan pernyataan kedua pakar pendidikan di atas, Umar Hasyim memberikan pandangan bahwa kasih sayang di dalamnya tidak boleh ada unsur pilih kasih. ${ }^{17}$ Sebab apabila demikian hanya akan menumbuhkan ketidakpuasan, putus asa,

14 Muhammad Anis, Quantum Al-Fätihah.... hlm. 63.

${ }^{15}$ Jaudah Muhamamad Awwad, Mendidik. Anak Secara Islam, terj. Shihabuddin ( Jakarta ; Gema Insani Press, 1995) hlm. 57.

16 Allen N. Mendler, Mendidik dengan Hati....hlm, 30-31.

${ }^{17}$ Umar Hasyim, Cara Mendidik, Anak dalam Islam, (Surabaya : Bina Ilmu, 1985)

hlm. 170 . 
pertengkaran, intrik dan fitnah perpecahan bahkan sampai pada tahapan durhaka atau melawan orangtua. Atau dapat pula menyebabkan timbul dendam dan permusuhan antara satu pihak dengan pihak lainya, atau satu remaja dengan remaja lainnya.

Berdasarkan beberapa asumsi di atas, penulis mengambil beberapa kesimpulan bahwa unsur dari kasih sayang antara lain:

a. Adanya saling menyamankan, saling mengharmonisasikan dan saling memberi "kesenangan positif" antara satu pihak terhadap pihak lainnya.

b. Adanya saling menghargai, toleransi, dan saling menghormati antara satu pihak terhadap pihak lainnya

c. Adanya unsur kedekatan emosional

d. Tidak adanya unsur kekerasan, penghinaan, umpatan, pemaksaan bahkan pemukulan

e. Tdak adanya unsur "pembeda-bedaan" atau "pilih kasih" antara satu pihak dengan pihak lain, atau satu remaja dengan remaja lainnya.

Setelah dipaparkan secara terpisah pengertian- baik secara bahasa maupun istilah — antara "pendidikan" dan "kasih sayang", berikut akan dipaparkan pengertian secara gabungan "pendidikan kasih sayang." Amstrong memberikan definisi perihal pendidikan kasih sayang ini yakni proses memanusiakan peserta didik dengan merekatkan hubungan positif antar pribadi yakni antara guru dan peserta didiknya, yang di dalamnya kental unsur pemahaman terhadap peserta didik, tidak adanya unsur menyalahkan dan unsur menuntut. ${ }^{18}$ Menurut penulis poin utama yang disampaikan Amstrong adalah adanya unsur "kerekatan sosial" dan "kelekatan antar individu" yang didahului dengan adanya "upaya" atau "usaha."Upaya inilah yang merupakan bagian dari "proses" memanusiawikan remaja, dengan kesantuan, kelembutan dan keramahan.

Pendidikan kasih sayang itu sendiri merupakan pembentukan intelektual individu yang kental muatan moralitas diri anak-remaja yang dibangun berdasarkan unsur-unsur yang tidak menjatuhkan anak atau remaja, menjauhkan dari konflik atau pertentangan, serta kontravensi. Hal yang demikian diutarakan pula

${ }^{18}$ T. Amstrong, Kids of Smart (New York : Penguin Group, 1993) hlm. 119. 
oleh Darmiyati Zuchdi yang memberikan asumsi bahwa pendidikan kasih sayang adalah suatu pemberian latihan intelektual dan moral untuk menyiapkan kehidupan pada masa yang akan datang dengan jalan damai, tanpa kekerasan, dan lebih meningkatkan pemahaman terhadap peserta didik sebagai individu. ${ }^{19}$

Pemahaman yang dimaksud adalah pemahaman yang mencerahkan anak. Pemahaman yang demikian dibarengi dengan interaksi dan kontal sosial yang berkelanjutan terhadap remaja. Sehingga remaja akan merasakan kedekatan yang tidak terputus dari figur lekatnya. Sehingga pula figur lekat akan dengan mudah masuk dalam kehidupan anak atau remaja.

Selanjutnya Dave Meier menyatakan bahwa pendidikan kasih sayang adalah usaha mengembangkan pribadi remaja dalam semua aspeknya dengan cara yang menyenangkan, menggembirakan, menciptakan suasana kedekatan hati, dan menciptakan makna yang berarti. ${ }^{20}$ Collin Rose dan Malcolm J. Nichols menyatakan bahwa pembelajaran yang dipenuhi hal-hal yang menyenangkan membawa dampak positif bagi remaja, di antaranya: Pertama, menciptakan lingkungan pembelajaran tanpa stress. Kedua, membangun emosional yang baik. Ketiga, Menggugah semangat remaja untuk belajar dan menstabilkannya. ${ }^{21}$

Pada substansinya, apa yang disampaikan Dave dan Collin memiliki kesamaan definsi, yakni sama-sama menciptakan suasana yang membangun kejiwaan positif terhadap anak dan remaja. Di samping itu sama-sama tidak mengedepankan kekerasan dan pemaksaan terhadap individu. Produk yang diunggulkan adalah "penciptaan suasana yang hangat dan komunikatif".

\section{Dasar Pendidikan Kasih Sayang}

Pada dasarnya konsepsi pendidikan kasih sayang telah disemaikan percontohannya di dalam ayat-ayat Al-Qur'an, dan sifatnya sangat beragam yang kesemuanya merupakan landasan dari

${ }^{19}$ Darmiyati Zuchdi, Humanisasi Pendidikan; Menemukan Kembali Penidikan yang Manusiani (Jakarta ; Bumi Aksara, 2010) hlm. 171-173.

${ }^{20}$ Dave Meier Dapat dilihat di Hernowo, Menjadi Guru yang Mau dan Mampu Mengajar Secara Menyenangkan, (Bandung: MLC, 2005) hlm. 175.

${ }^{21}$ Collin Rose dan Malcolm J. Nicholl, Acceletared Learning for The 21ts, Cara Belajar Cepat Abad XXI, ter. Dedy Ahimsa, Cet. 6 (Bandung : Nuansa, 2006) 
pendidikan kasih sayang. Dasar ayat al-Qur'an tentang pendidikan kasih sayang yang terlihat jelas dari sekian banyak ayat-ayat lainnya adalah pendidikan Luqman terhadap anaknya yang benar-benar mengedepankan pendidikan kasih sayang. Beberapa ayat yang menujukkan hal tersebut antara lain; Pertama, Q.S Lukman ayat 11, yang dengan lemah lembut Lukman menasehati anaknya untuk tidak menyekutukan Allah. Bahasa yang digunakan adalah "wahai anakku", kalimat ini adalah kalimat yang "halus-lembut" yang tidak bernada kesombongan orang tua, arogansi orang tua, tidak bernuansa amarah yang ditunjukkan orang tua kepada anaknya. Nada yang demikian itulah yang "tidak banyak" digunakan oleh orang tua maupun pengajar sekarang ini, mereka lebih mengedepankan arogansi-diri. Sehingga menjauhkan emosi-afeksi antara orang tua dan anak.

Kedua, QS. Lukman ayat 17 yang dengan bahasa santun terhadap anaknya untuk "mendirikan shalat" bukan sebatas "mengerjakan shalat", Lukman meminta dan mengarahkan sang putra untuk tidak meninggalkan shalat sebab shalatlah sebagai "pencegah kemungkaran" dan "pembawa keberkahan". Komunikasi dua arah antara Lukman dan anaknya inilah yang dikedepankan dan kembangkan sehingga antara orang tua dan anak dalam hal ini Lukman dan anaknya terjadi "penyatuan rasa."

Ayat lain yang masih berhubungan dengan pendidikan kasih sayang Lukman terhadap anaknya, yang dapat dijadikan percontohan adalah nasehat bijaksana Lukman terhadap anaknya untuk tidak bersikap sombong, congkak, adigang adigung adiguna. Ayat Qur'an yang menunjukkan akan bahasan tersebut adalah QS. Lukman ayat 18. Lukman dengan penuh bijaksana memberikan nasehat mendalam tanpa adanya nuansa horror dan mencemaskan anak. Hal-hal yang demikian itulah yang seyogyanya diteladani oleh masyarakat, agar tercipta pendidikan anak yang masuk di hati, bukan hanya sekedar "kiasan/formalitas belaka.

\section{Urgensi Pendidikan Kasih Sayang}

Kasih sayang menjadi sangat penting bagi dunia "educating" dan "parenting" dalam sepajang zaman. Tidak hanya pada era modernisasi sekarang ini, tetapi pada zaman para nabi pun kasih sayang sudah diterapkan sebagai metode dalam "mendidik"; baik mendidik remaja, istri/suami, keluarga dan masyarakat saat itu. Sebagai contohnya, Nabi Adam dapat ditunjukkan rasa cinta dan sayangnya Adam terhadap 
istrinya Hawa, yang begitu besar, sehingga Adam rela melanggar janji kepada Allah untuk tidak memakan buah quldi, demi memenuhi keinginan Hawa. Demikian pula sayangnya Nabi Nuh terhadap remaja dan istrinya yang membangkang meski dengan kesabaran dan nasehat yang lembut, tetap saja keduanya tidak beriman dan lebih memilih kemungkaran(QS. Hūud ayat 42-43).

Nabi Ibrahim pun demkian, begitu sayang terhadap ayahnya "pembuat patung berhala." Tidak henti-hentinya Ibrahim memberikan wejangan dan nasehat dengan lembut dan santun terhadap ayahnya agar kembali ke jalan illabi rabbi. Meskipun hasilnya nihil. Ibrahim tidak menginginkan ayahnya menjadi hamba-hamba syaithan yang menyebarkan kesesatan kepada umat manusia sedangkan dirinya menjadi "penerang kegelapan para umat."

Hal demikian pula nabi Sulaiman yang menunjukkan kasih sayang besarnya terhadap para binatang dan kaum jin. Persahabatan mereka dengan Sulaiman benar-benar dilandasi karena Allah semata. Di sisi lain ada pula nabi Yusuf yang menunjukkan kebesaran hati dan sayangnya terhadap saudara-saudara yang telah mencelakakannya memasukkan ke kubangan sumur. Meski dianiaya, tetapi Yusuf tidak menunjukkan kebencian dan pembalasan terhadap mereka, bahkan malah sebaliknya mengangkat derajat-duniawi mereka ke dalam pemerintahan masa itu.

Dengan demikian kasih sayang hendaknya ada dan terjaga baik dalam berbagai hal keadaan. Kasih sayang yang dimaksud adalah kasih sayang yang murni dari ketulusan hati. Sejatinya keberadaan pendidikan dengan kasih sayang memberikan manfaat besar bagi umat, hal ini dijabarkan pula oleh para pakar pendidikan; Muhammad Usman Najati memberikan asumsinya bahwa dengan pendidikan cinta dan kasih sayang yang baik maka akan memberikan dampak positif terhadap remaja, di antaranya : ${ }^{22}$

a. Dengan cinta dan kasih sayang diharapkan dapat menjadi media “pelatih' remaja untuk mudah mencintai orang lain, mudah mencintai sesama. Tidak memiliki sifat individualistis. Dan menciptakan "kepedulian sosial"

b. Dengan cinta dan kasih sayang diharapkan akan mampu melatih diri remaja untuk mencintai dan menghargai dirinya sendiri sehingga remaja akan memperlakukan dirinya dengan baik, tidak

22 Muhammad Usman Najati, Al-Qur'ān dan Psikologi, terj. Ade Asnawi Syihabuddin, (Jakarta : Aras Pustaka, 2002) hlm. 50. 
menyimpangkan diri sendiri ke hal-hal negatif.

Senada dengan pernyataan Najati di atas, Sayid Nasir

Hasyemi pun memberikan pandangan bahwa pendidikan kasih sayang memiliki beberapa urgensi, di antaranya adalah : ${ }^{23}$

a. Pendidikan kasih sayang menciptakan kerja sama yang baik di antara sesama, sebab bila kasih sayang hilang maka persaudaraan dan kerjasama pun akan hilang.

b. Pendidikan kasih sayang juga menyebabkan keselamatan jasmani dan ruhani, menjadi solusi tepat dalam memperbaiki perilaku amoral dan mengharmoniskan hubungan manusia.

c. Pendidikan kasih sayang memicu ketaatan dan kebersamaan.

d. Pendidikan kasih sayang menyebabkan kelembutan sikap anak dan remaja. Remaja yang tumbuh dalam lingkungan keluarga yang penuh kasih sayang dan perhatian akan memiliki kepribadian yang mulia, lebih suka mencintai orang lain dan berperilaku baik dalam masyarakat. Kehangatan cinta dan kasih sayang yang diterima remaja akan menjadikan kehidupan mereka bermakna, membangkitkan semang- at, melejitkan potensi dan bakat yang terpendam, serta mendorong untuk bekerja/berusaha secara kreatif.

e. Dengan pendidikan kasih sayang dan hubungan tulus serta harmonis, orang tua dapat mencegah anak-anak mereka dari melakukan perbuatan tercela dan mengarahkan mereka menuju tindakan yang mulia dan luhur. Kasih sayang merupakan kunci menuju kesempurnaan dan pendidikan yang ideal.

Asumsi penulis melihat pernyataan dua pakar di atas bahwa pendidikan kasih sayang mengarahkan anak dan remaja pada term kejiwaan yang sehat. Hal inilah yang dituju oleh banyak kalangan. Dengan pendidikan kasih sayang akan semakin meluaskan jiwa, fikiran, dan perilaku anak dan remaja, sehingga kondisi individual yang telah terbangun dengan baik akan mempengaruhi kondisi lingkungan sosial yang turut baik pula.

Dengan kata lain, pendidikan kasih sayang akan menjauhkan anak dan remaja pada perilaku menyimpang, yang meresahkan kondisi lingkungan sosial. Sebagaimana disampaikan oleh Muhammad al-

${ }^{23}$ Sayid Nasir Hasyemi, Peran Kasib Sayang dalam Pendidikan, http://www.taghrib ir/indonesia/index.php?option $=$ com_content\&view $=$ article\&id=151:peran-kas ihsayang-dalam-pendidikan\&catid=35:1388-06-21-07-28-12\&Itemid=54 
Zuhaili yang berpendapat bahwa dengan pendidikan kasih sayang yang penuh akan membantu menghilangkan atau menghindari atau pula menyembuhkan dari berbagai bentuk penyimpangan remaja dari dunia luar yakni dari penyimpangan moral, penyimpangan berpikir, penyimpangan agama, penyimpangan sosial dan hukum, penyimpangan mental dan penyimpangan ekonomi. ${ }^{24}$

Asumsi penulis bahwa berbagai penyimpangan pada dasarnya dapat diatasi dengan cara melihat sumber dari penyakit tersebut. Ketika sumber tersebut adalah problem keluarga inti yang tidak menyamankan kehidupan anak dan remaja di dalam keluarga, maka keluarga inti merubah pola pendekatannya terhadap anak atau remaja. Menyuburkan kasih sayang. Sehingga masalah personal tidak meluas pada masalah sosial yang notabene merupakan penyimpangan yang berbahaya.

Merujuk pada pendapat para ahli di atas, dapat disimpulkan oleh penulis bahwa fungsi penerapan pendidikan kasih sayang terhadap anak dan remaja adalah:

1. Menciptakan keharmonisan individu remaja dan sosial

2. Membangun kecerdasan intrapersonal dan interpersonal pada remaja

3. Menumbuhkan kecerdasan emosional remaja

4. Membangun kepercayaan diri remaja dan memotivasi untuk bangkit dari "kesalahan, penyimpangan dan kejahatan yang selama ini dibuat, dan menuju "kebaikan sikap dan perilaku"

5. Membantu remaja menyuburkan kecerdasan afeksi dan kecerdasan spiritual, sehingga dapat memaknai keberadaan

${ }^{24}$ Muhammad al-Zuhaili, Menciptakan Remaja Dambaan Allab Panduan bagi Orang Tua Muslim, (Bandung : PT Mizan Pustaka, 2004) cet. Ke-1, hlm. 149-151. Pertama, penyimpangan moral terjadi disebabkan oleh seseorang yang meninggalkan perilaku baik dan mulia, lalu menggantinya dengan perbuatan buruk, seperti cepat terbawa arus, tidak menjaga kehormatan diri, tawuran, seks bebas, gaya hidup bebas, gaya hidup kebaratbaratan. Kedua, Penyimpangan berpikir timbul karena kekosongan pikiran, kekeringan rohani dan kedangkalan keyakinan, misalnya fanatik yang berlebihan, khurafat, tahayul. Ketiga, Penyimpangan agama yakni terlihat dari sikap ekstrem seseorang dalam memahami ajaran agama sehingga ia fanatik terhadap mazhab atau kelompoknya, atau pula dia skeptis terhadap keyakinannya sendiri. Keempat, penyimpangan sosial dan hukum dapat dilihat dari sikap yang selalu melakukan kekerasan seperti mengancam, merampas, membunuh, narkoba, kecanduan minuman keras dan penyimpangan seksual. Kelima, penyimpangan mental dapat dilihat dari sikap yang selalu merasa tersisih, kehilangan kepercayaan diri, memiliki kepribadian ganda, kehilangan masa depan, bimbang dan sering bingung. Keenam, penyimpangan ekonomi yakni berbentuk congkak dan gengsi dengan kekayaan yang dimiliki, boros, berfoya-foya, glamour, dan materialistis. 
illabi yang ber-efek pada kehati-hatian remaja dalam bersikap dan bertindak.

6. Membantu menumbuhkan dan menstabilkan kecerdasan adversity pada remaja, sehingga remaja mampu menteladani hikmah-hikmah yang telah terjadi.

\section{E. Prinsip-prinsip Pendidikan Kasih Sayang}

Prinsip dalam bahasa Inggris berasal dari kata principle yang berarti asas atau dasar. Dalam Kamus karya Wojowasito dan Poerwadarminta principle diartikan dasar, permulaan, aturan pokok, prinsip dan asas. ${ }^{25}$ Dalam Kamus Besar Bahasa Indonesia prinsip diartikan sebagai kebenaran yang menjadi pokok dasar berpikir, bertindak atau dasar. ${ }^{26}$ Wikipedia Bahasa Indonesia, Ensiklopedia Bebas memberi definisi perihal prinsip ini yakni suatu pernyataan fundamental atau kebenaran umum maupun individual yang dijadikan oleh seseorang atau kelompok sebagai sebuah pedoman untuk berpikir atau bertindak. ${ }^{27}$ Sebuah prinsip merupakan roh dari sebuah perkembangan ataupun perubahan dan merupakan akumulasi dari pengalaman ataupun pemaknaan oleh subyek atau obyek tertentu.

Dengan demikian - berdasar definsi di atas - prinsip dapat diartikan sebagai landasan atau sandaran, atau pula asas untuk bertindak selanjutnya, yang dalam hal ini dasar atau asas untuk menciptakan pendidikan kasih sayang. Kasih sayang secara vertikal dan horisontal yakni kasih sayang kepada Allah. Dzat yang Maha Kuasa, dan kasih sayang kepada sesama manusia, yang di dalamnya termuat kasih sayang antara remaja dengan orang tua atau sebaliknya. Antara guru dengan peserta didik atau pula sebaliknya, antara tetangga dan saudara, kaum miskin, kaum jalanan, dan kepada segala makhluk di alam ini. Dengan kasih sayang inilah akan mewujudkan kebahagiaan yang hakiki.

Sebuah artikel yang berjudul "7 Prinsip Pendidikan Tanpa Kekerasan", artikel ini memuat hal-hal yang perlu dilestarikan guna mewujudkan keharmonisan dalam mendidik, mengarahkan dan memberi bimbingan terhadap remaja tanpa kekerasan dan

\footnotetext{
${ }^{25}$ Wojowasito dan W.J.S Poerwadarminta, Kamus Lengkap Inggeris-Indonesia, Indonesia-Inggris (Bandung : Media IPTEK, 2007) hlm. 159.

${ }^{26}$ Departemen Pendidikan Nasional, Kamus Besar Bahasa Indonesia Edisi Ketiga (Jakarta : Balai Pustaka, 2002) hlm. 896.

${ }^{27}$ Wikipedia Bahasa Indonesia,Ensiklopedia Bebas, http ://id.wikipedia.org/wiki/prinsip
} 
mengembangkan kasih sayang, 7 prinsip tersebut yakni : ${ }^{28}$

Gambar 1

\section{Prinsip Pendidikan Kasih Sayang Tanpa Kekerasan}

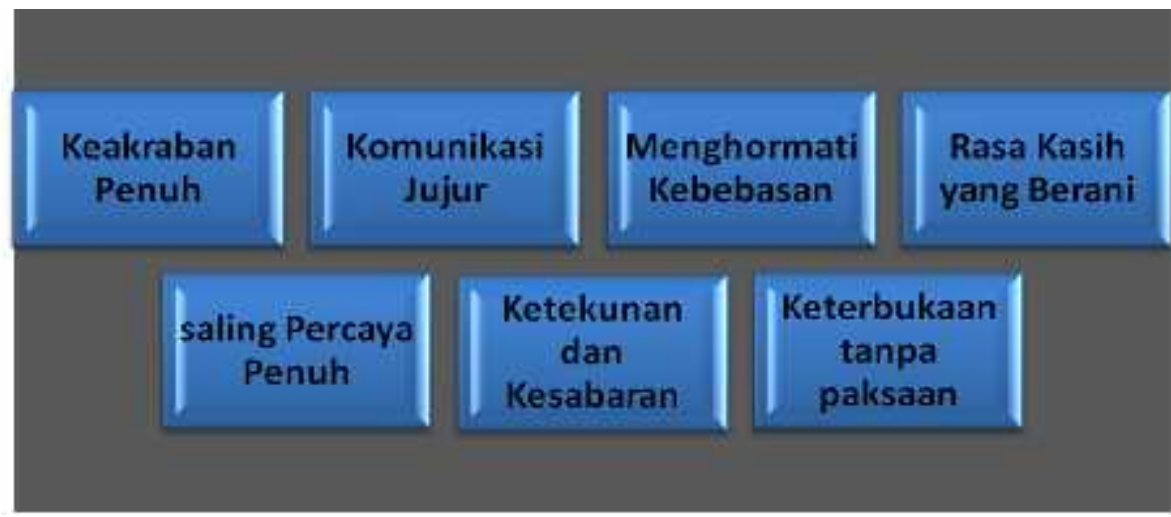

Sumber : http:/ /www. wikimu .com/ News /DisplayNews.aspx?id=14997

Keakraban penuh menjadi salah satu poin dasar untuk menciptakan suasana kental kasih sayang. Hal ini disebabkan di dalam keakraban terdapat unsur kasih sayang, keramahan, sopan-santun, saling menghargai dan menghormati. Mendidik remaja yang baik harus mendekat dan mengerti apa yang diinginkan dan dirasakan remaja. Tidak ada pembatas antara orang tua dan remaja, atau antara pendidik dan yang terdidik, antara yang merawat dan yang dirawat, antara pembimbing dan yang dibimbing. Keduanya harus menyatu padu.tidak ada sekat yang menyertainya.

Komunikasi yang jujur merupakan hal penting yang idealnya diterapkan untuk mendidik remaja. Tidak boleh di dalamnya labw alhadits yang diterjemahkan sebagai kebohongan cerita atau cerita palsu dan al-ifle yang diartikan sebagai hal mengada-ada. Karena yang demikian hanya akan melahirkan remaja sebagai bibit-bibit pembohong baru.Menghormati kebebasan remaja - kebebasan yang dimaksud adalah kebebasan yang bertanggung jawab- merupakan kewajiban

287 Prinsip Pendidikan Tanpa Kekerasan, http:/ /www. wikimu .com/ News 
seorang pendidik, pembimbing, pengajar, maupun orang tua. Dalam hal ini remaja diberi kebebasan untuk mengenal diri, mencari jati diri, memahami diri, dan mengapresiasikan talenta-nya. Tidak adanya pembatas, pengekangan serta aturan-aturan ketat dan mengikat penuh yang pada akhirnya hanya akan membelenggu kebebasan remaja untuk berekspresi.

Rasa kasih yang berani perlu dimunculkan dan bahkan terus dikembangkan untuk senantiasa mengasihi remaja. Kasih yang berani disini dapat ditujukan terhadap remaja-remaja yang menyimpang seperti remaja jalanan, remaja punk, remaja korban narkoba, remaja-remaja nakal lainnya. Seorang guru, pendidik, pembimbing maupun orang tua harus berani memberikan kasih sayang yang tulus, untuk mengubah keadaan mereka menuju kebaikan sikap dan tingkah laku. Tidak boleh ada pembeda atau pilih kasih di antara remaja yang sehat dan yang tidak sehat, sebab yang demikian hanya akan menambah beban mereka yang tidak sehat, dan makin menjadikan terperosok dalam, sehingga kesembuhan bagi mereka adalah kemustahilan.

Saling percaya penuh juga merupakan salah satu prinsip menuju kasih sayang sehat. Seorang pendidik, pembimbing, pengajar atau pun orang tua harus menerapkan prinsip saling percaya. Orang tua belajar untuk mempercayai remaja; percaya untuk bertanggung jawab secara mandiri, yang tidak meniadakan "pengawasan tanpa batas" artinya orang tua ataupun pendidik tetap memberikan pengawasan dan bimbingan bijaksana terhadap remaja tanpa adanya kata "selesai' atau tanpa adanya pangkal ujung, terus dan terus memberikan kepercayaan, wejangan dan nasehat menuju kebaikan remaja.

Mengajar, membina dan mendidik remaja membutuhkan ketekunan dan kesabaran. Terutama terhadap remaja yang memiliki gangguan kesehatan jiwa, lebih memaksimalkan kesabaran. Sebab modal utama dari "perubahan akhlak remaja" adalah kesabaran dan ketekunan dalam membina dan mendidik. Semakin tinggi kualitas sabar seorang pembimbing, pendidik dan orang tua terhadap remaja, maka akan semakin cepat remaja yang bermasalah sembuh dari penyakitnya. Tetapi semakin rendah kualitas sabar seorang pembimbing, pendidik dan orang tua maka semakin jauh remaja sembuh dari penyakitnya.

Hal selanjutnya adalah keterbukaan tanpa paksaan. Suasana kasih sayang yang penuh dapat dilihat dari bagaimana antara kedua belah pihak yakni antara orang tua, pembimbing, pengajar, dan remaja saling terbuka tanpa adanya kata “paksaan'. Si remaja dengan tulus 
menceritakan semua permasalahan diri terhadap pihak pertama (seperti orang tua, pembina atau pendidik). Atau pula remaja menceritakan segala hal yang ditemui dalam keseharian tanpa adanya rasa malu, benci, tidak suka dan sebagainya. Semuanya mengalir dengan bijaksana. Dengan suasana penuh keterbukaan inilah seorang pendidik, pembimbing, pengajar maupun orang tua dapat menggunakan kesempatan tersebut untuk pengarahan dengan santun, pembimbingan positif dengan lembut, dan pemberian nasehat dengan bijak.

Nur Ahid dalam karyanya menambahkan di dalam kasih sayang harus ada prinsip keadilan ${ }^{29}$, yakni peniadaan pilih kasih terhadap remaja, sebagaimana Nabi bersabda dalam Musnad Ahmad ibn Hanbal yang terjemahannya berbunyi : ${ }^{30}$

"Berlaku adillah kamu di antara remaja-remajamu, berlaku adillah kamu di antara remaja-remajamu, berlaku adillah kamu di antara anak-anakmu."

Abdullah Nashih Ulwan memberikan tambahan yang menyangkut prinsip-prinsip pendidikan kasih sayang ini yakni adanya prinsip kesantunan dalam bersikap dan bertutur kata terhadap remaja. Menurut Nashih Ulwan kesantunan merupakan keutamaan spiritual dan moral yang paling besar yang mengakibatkan manusia dalam puncak keluhuran akbläk. ${ }^{31}$

\section{F. Pendidikan Kasih Sayang Sebagai Suatu Pendekatan}

Di dalam tema pendidikan baik itu pendidikan konvensional maupun Pendidikan Islam dikenal dengan istilah pendekatan atau dalam bahasa Inggrisnya dikenal dengan istilah "approach", yang dapat diartikan sebagai "came near (menghampiri), go to (jalan ke) dan way path dengan (arti jalan)." Dilihat dari segi bahasa tersebut dapat diterjemahkan bahwa yang dinamakan approach adalah cara menghampiri atau mendatangi sesuatu. ${ }^{32}$

Adapun pendekatan dari segi istilah menurut beberapa ahli dinyatakan bahwa: Habib Thaha mendefiniskan pendekatan adalah

${ }^{29}$ Nur Ahid, Pendidikan Keluarga dalam Perspektif Islam, hlm., 118.

${ }^{30}$ Ahmad ibn Hanbal, Musnad Ahamad Ibn Hanbal, Jilid IV (Bairut : Dar Sadir, tt) hlm. 375 .

${ }^{31}$ Abdullah Nashih Ulwan, Pedoman Pendidikan Anak dalam Islam, hlm. 184.

${ }^{32}$ Pendekatan dalam Pendidikan Islam, http://ululazmizabaz.blogspot.com/2011/03/pendekatan-dalam-pendidikan-islam_25.html 
cara pemrosesan subyek atas obyek untuk mencapai tujuan. Pendekatan ini juga berarti cara pandang terhadap sebuah obyek permasalahan, di mana cara pandang tersebut adalah cara pandang yang luas. Sedangkan Oteng Sutisna lebih praktis dalam memahami pengertian "pendekatan". Pendekatan adalah apa yang hendak ia kerjakan dan bagaimana ia akan mengerjakan sesuatu, yang pertama disebut dengan pendekatan pengertian "tugas" dan yang kedua adalah pendekatan dalam pengertian "proses". 33

Penggunaan istilah "pendekatan" memiliki arti yang berbeda-beda tergantung kepada obyek apa yang akan menjadi tema sentral perencanaan kerja dan kajian pemikiran yang akan dikembangkan. Dalam konteks belajar, approach dipahami sebagai segala cara atau strategi yang digunakan peserta didik untuk menunjang efesiensi dan efektifitas dalam proses pembelajaran tertentu. Dengan demikian sesungguhnya approach adalah seperangkat langkah operasional yang direkayasa sedemikian rupa, untuk memecahkan masalah atau untuk mencapai tujuan belajar tertentu. ${ }^{34}$

Pendekatan dalam kajian pendidikan memiliki beberapa jenis, di antaranya: Pertama, pendekatan sains; Kedua, pendekatan filosofi; dan Ketiga, pendekatan religi. Pendekatan sains lebih tertuju kepada pengkajian pendidikan untuk menelaah dan dan memecahkan masalah-masalah pendidikan dengan menggunakan disiplin ilmu tertentu sebagai dasarnya. Sedangkan pendekatan filosofi suatu pendekatan untuk menelaah dan memecahkan masalah-masalah pendidikan dengan menggunakan metode filsafat. Sedangkan pendekatan religi adalah suatu pendekatan untuk menyusun teori-teori pendidikan dengan bersumber dan berlandaskan pada ajaran agama. Di dalamnya berisikan keyakinan dan nilai-nilai tentang kehidupan yang dapat dijadikan sebagai sumber untuk menentukan tujuan, metode bahkan sampai dengan jenis-jenis pendidikan. ${ }^{35}$

Jalaluddin Rahmat dan Zaenal Abidin Ahmad merumuskan pendekatan dalam Islam, yang antara lain : ${ }^{36}$

${ }^{33}$ Oteng Sutisna, Administrasi Pendidikan Dasar Teoristis untuk Praktek Profesional, (Bandung: Angkasa, 1983) hlm. 35-36

${ }^{34}$ Pendekatan dalam Pendidikan Islam, http://ululazmizabaz.blogspot.com/2011/03/pendekatan-dalam-pendidikan-islam_25.html ${ }^{35}$ Pendekatan-pendekatan Teori Pendidikan, http://elearning.unesa.ac.id/tag/contoh-makalah-pendekatan-dalam-teori-pendidikan

36 Ada pada buku Abdul Mujib\& Jusuf Mudzakkir, Ilmu Pendidikan Islam, (Yogyakarta : Kencana Prenada Media, 2006) hlm. 177-178 
1. Pendekatan Tilāwah (pengajaran), merupakan pembacaan diri terhadap ayat-ayat Allah baik ayat-ayat qauliyyah maupun kauniyyah, dengan tujuan untuk mengagungkan kebesaran dan ciptaan-Nya. Bentuk dari pendekatan ini adalah tafakkur (berpikir) dan tadżakkur (berdzikir). Dengan bentuk penerepannya adalah kelompok pengajian dan pengkajian, contextual learning, kegiatan ilmiah yang konstruktif.

2. Pendekatan Tazkiyyah (Penyucian), yakni mengedepankan konsep pensucian diri dari segala kemungkaran dan keburukan sikap, hati dan perbuatan. Tujuan dari pendekatan ini adalah melahirkan manusia-manusia baru yang beradab, berakhlak, dan berhati bersih, sehingga perilakunya tidak merusak tatanan kehidupan yang sudah berjalan baik dalam masyarakat maupun keluraga. Bentuk dari pendekatan ini adalah: ceramah, mubāsabah diri, muhāsabah musik, mubāsabah di tempat-tempat yang mustajabah.

3. Pendekatan Ishlah (Perbaikan), yakni pelepasan beban dan belenggu-belenggu yang bertujuan memiliki kepekaan sosial (rasa solidaritas yang tinggi), sehingga lebih banyak melakukan instropeksi diri untuk menuju perbuatan diri yang mulia dan bermanfaat bagi sosial. Wujud dari pendekatan ini adalah: kampanye amal saleh, membudayakan sedekah, kunjungan terhadap kaum papa.

4. Pendekatan Ta'lim al-Kitab, yakni pengajaran atas al-Qur'ān. Memaknai esensi yang ada pada al-Kitab, yang selama ini hanya dibaca tanpa tahu makna yang sesungguhnya. Wujud pendekatan ini adalah: kelompok diskusi, lomba kreativitas yang bersifat qur'ani, pembedahan literatur islam yang berhubungan dengan Qur'āni.

Menurut Syaiful Bachri Djamarah, ada beberapa pendekatan yang diketemukan dalam proses pembelajaran pendidikan agama Islam adalah, yakni $:^{37}$

1. Pendekatan Pengalaman, yakni pemberian pengalaman dan memahamkan terhadap berbagai pengalaman yang dialami oleh remaja dengan tujuan penanaman nilai-nilai keagamaan baik secara individual maupun kelompok dan memberikan pelajaran

37 Syaiful Bachri Djamrah dan Aswan Zain, Strategi Belajar Mengajar, (Jakarta, PT. Rineka Cipta, 1997) hlm. 70 
serta peringatan kepada semua manusia agar mereka tidak terjerumus dalam situasi dan perbuatan yang sama.

2. Pendekatan Pembiasaan, yakni suatu pendekatan kepada remaja di mana remaja diarahkan untuk "membiasakan sesuatu" atas hal-hal yang direncanakan dan sifatnya baik. Sehingga remaja akan terbiasa untuk melakukan hal-hal positif dalam kehidupan sehari-hari.

3. PendekatanEmosional, yakni suatu pendekatan yang mengedepankan nuansa kehalusan jiwa, ucapan, perilaku dan kesantunan serta penghargaan kepada remaja. Arah dari pendekatan emosional adalah sense of intrapersonal dan sense of interpersonal.

4. Pendekatan Keteladanan, yaitu suatu pendekatan di mana remaja diajarkan untuk menteladani perilaku yang baik, dan mulia. Sehingga remaja akan memiliki panutan untuk berbuat baik dalam perilaku sehari-hari.

Apabila dilihat dari term tema kajian ini maka pendidikan kasih sayang merupakan salah satu bentuk dari pendekatan emosional, yakni pendekatan kepada anak/peserta didik yang lebih menggunakan hati, menggunakan perasaan sayang, komunikasi yang jujur, saling percaya penuh, keterbukaan tanpa paksaan, dan keakraban penuh.

Pendekatan emosional ini mengandung unsur-unsur yang sama dengan yang ada pada pendidikan kasih sayang, yakni: adanya unsur pemahaman, persahabatan, toleransi, pemberian motivasi positif, adanya pujian yang tulus dan tidak memaksa, adanya unsur kenyamanan dan unsur penghargaan kepada remaja. Sehingga yang diharapkan remaja akan termotivasi menjadi "baik" dan bahkan "menjadi lebih baik".

Berbeda bila remaja didekati dengan pendekatan yang memaksa, rasa penghargaan yang minim, krisis kenyamanan, persahabatan yang dipaksa maka yang terjadi remaja - apalagi yang dimaksud adalah remaja nakal — akan semakin jauh dan atau menjauh dari kebaikan perilaku. Hal ini akan merugikan semua pihak.

\section{G. Kontribusi Pendidikan Kasih Sayang Terhadap Ranah Psikologi Pendidikan Islam}

Dalam ranah Psikologi Pendidikan Islam yang kaitannya erat dengan dunia jiwa anak (peserta didik), pendidikan kasih sayang menjadi simbol yang tidak bisa dihilangkan dan tidak bisa dihapuskan, 
sebab memiliki high value atau nilai yang tinggi yang menjadi peganganerat untuk berbuat, terutama kepada anak/peserta didik. Manakala pendidikan kasih sayang tidak diterapkan maka akan "berjalan timpang" yang menyebabkan akan terjadi "krisis afeksi" sehingga akan semakin menjauhkan dari konsep "barakah, mawaddah dan rahmah" di dalam hubungan antara anak dan orang tua atau guru dengan anak didiknya.

Hal terpenting lagi ketika yang dijadikan rujukan dan 'uswah hasanah'- dalam kajian Psikologi Pendidikan Islam perihal mendidik anak dengan kasih sayang - adalah al-Qur'an dan Sunnah, hal yang jauh berbeda dengan kajian Psikologi Pendidikan modern yang rujukannya adalah rasionalitas manusia, sehingga menghilangkan aspek ruhani. Akibatnya, pendekatan yang digunakan terhadap anak/peserta didik adalah pendekatan rasio-kognitif, pendekatan yang hanya menyentuh ranah keilmuan-akal saja, tetapi minim sentuhan batiniyyah.

Padahal sejatinya berbeda, pendidikan kasih sayang kepada anak/peserta didik kental dengan nuansa ruhaniyyah dengan pendidikan kasih sayang kering nuansa ruhaniyyah dan kental nuansa rasio-kognitif. Perbedaannya terletak pada atsar (bekas) yang dirasakan pada anak/peserta didik, selain itu terletak pula pada rasa (sense).Pendidikan kasih sayang yang dilambari dengan nuansa ruhaniyyah akan sangat terasa atsar-nya dalam kehidupan sehari-hari, tidak masuk pada ranah 'kamuflastik' atau 'manipulatif tetapi benarbenar mampu merubah anak/peserta didik dari relung hati yang terdalam, di sisi lain rasa yang dialami pun adalah rasa kedamaian, kenyamanan dan pencerahan diri pada anak/peserta didik.

Sebagaimana yang dinyatakan dalam buku Kepribadian dalam Psikologi Islam karya Abdul Mujib, dijelaskan bahwa sentuhansentuhan jiwa yang spiritualis (yang dekat dengan illahi) perlu ditekankan kepada anak didik untuk membantu "merubah kebiasaan tidak bertanggung jawab", "merubah perilaku buruk", sebab sentuhan jiwa yang spiritualis lebih bersifat langsung dan mengena yang diharapkan akan bersifat "langgeng pada anak." 38

Pernyataan tersebut ditegaskan pula dengan hasil disertasi Sayekti yang menyatakan bahwa pendekatan agama dan nilai-nilai spiritual sangat besar pengaruhnya terhadap keberhasilan penyembuhan terhadap anak/peserta didik bermasalah, terutama nilai-nilai agama

${ }^{38}$ Abdul Mujib, Kepribadian dalam Psikologi Islam, Jakarta: PT Raja Grafindo Persada, 2006) hlm. 113 
yang disebarkan di dalam keluarga. ${ }^{39}$ Muhammad Tholchah Hasan memberikan asumsi bahwa suasana yang penuh religious-spiritual membantu menstabilkan hati dan mengarahkan pada kedamaian dan ketenangan jiwa dan perilaku. ${ }^{40}$

Dari beberapa pernyataan tersebut di atas terlihat bahwa pendidikan kasih sayang yang kental nuansa agamis-religius yang sifatnya menjiwa akan lebih berfungsi-aktif bagi anak/peserta didik. Lain halnya manakala pendekatan kasih sayang yang kering nuansa agamis-religius dan terpusat pada ranah kognitif semata, yang terjadi anak akan berubah pada tataran konsep-akal-kognitif semata tetapi secara jiwa mereka mengalami kekeringan, sehingga perilaku yang dimunculkan adalah perilaku-kamuflastik, yang sifatnya tidak mengena dan tidak langgeng pada anak didik.

Oleh karena itulah pendidikan kasih sayang dalam kajian Psikologi Pendidikan Islam menjadi sangat urgen/penting karena adanya sesuatu hal yang menjadi ciri khas di dalamnya yakni 'adanya penyampaian pendidikan kasih sayang kepada anak/peserta didik yang didasari pada aspek qalb, ruhaniyyah'sehingga lebih mengena dan terasa, dan yang demikian hendaknya dibudayakan dan dikembangkan lebih luas pada ranah madrasah/sekolah di manapun berada.

\footnotetext{
${ }^{39}$ Pujosuwarno Sayekti, Makna Integrasi Antaranggota Keluarga Dipandang dari Sudut Konseling Keluarga, seri disertasi (PPS IKIP Bandung, 1991), tidak dipublikasikan.

${ }^{40}$ Muhammad Tholchah Hasan, Dinamika Kehidupan Religius, Jakarta : Listafariska Putra, 2000), hlm. 153.
} 


\section{H. Kesimpulan}

Pendidikan kasih sayang mutlak dikembangkan tidak hanya pada tataran konseptual tetapi juga pada tataran aplikatif, pusat pengembangannya distressingkan pada dunia anak/peserta didik, Sebab di tangan anak inilah masa depan bangsa dan negara ditentukan. Sehingga apabila pendekatan yang dikedepankan orang tua atau pendidik kepada anak bukan pendekatan pendidikan kasih sayang, tetapi kekerasan akan berdampak buruk terhadap anak/peserta didik. Hal tersebut tentunya akan mengganggu kestabilan perkembangan anak. 


\section{DAFTAR PUSTAKA}

Abdul Mujib, Kepribadian dalam Psikologi Islam, Jakarta: PT Raja Grafindo Persada, 2006

Abdul Mujib\& Jusuf Mudzakkir, Imu Pendidikan Islam, Yogyakarta : Kencana Prenada Media, 2006

Ahmad ibn Hanbal, Musnad Ahamad Ibn Hanbal, Jilid IV, Bairut : Dar Sadir, tt

Ahmad Warson. Munawwir, Kamus al-Munawwir Arab-Indonesia Terlengkap,Surabaya, Pustaka Progressif, 2002

Amstrong, Kids of Smart (New York : Penguin Group, 1993

Baiquni dkk., Indeks al-Qur'an Cara Mencari ayat Al-Qur'an, Surabaya : Penerbit Arloka, 1996

Busyairi Madjidi, Konsep Pendidikan Para Filosof Muslim,Yogyakarta : al- Amin Press, 1997

Collin Rose dan Malcolm J. Nicholl, Acceletared Learning for The 21 ${ }^{\text {st }}$, Cara Belajar Cepat Abad XXI, ter. Dedy Ahimsa, Cet. 6 (Bandung : Nuansa, 2006

Darmiyati Zuchdi, Humanisasi Pendidikan ; Menemukan Kembali Penidikan yang Manusiawi Jakarta ; Bumi Aksara, 2010

Departemen Pendidikan Nasional, Kamus Besar Babasa Indonesia, Jakarta : Balai Pustaka, 2002 Edisi Ketiga

DuaneSchualtz, Psikologi Pertumbuhan Model-model Kepribadian Sehat, penerj. Yustinus, Yogyakarta : PT Kanisius, 1991

Hernowo, Menjadi Guru yang Mau dan Mampu Mengajar Secara Menyenangkan, Bandung : MLC, 2005

Jaudah Muhamamad Awwad, Mendidik Anak Secara Islam, terj. Shihabuddin, Jakarta ; Gema Insani Press, 1995

Mahmud Yunus, Kamus Arab-Indonesia, Jakarta : Hidakarya Agung, 1990

Muhammad Anis, Quantum al-Fatihah ; Membangun Konsep Pendidikan Berasis Surah al-Fatihah, Yogyakarta : Pedagogia, 2010

Muhammad Usman Najati, Al-Qur'ān dan Psikologi, terj. Ade Asnawi Syihabuddin, Jakarta : Aras Pustaka, 2002

Muhammad al-Zuhaili, Menciptakan Remaja Dambaan Allah Panduan bagi Orang Tua Muslim, Bandung : PT Mizan Pustaka, 2004

Muhammad Tholchah Hasan, Dinamika Kehidupan Religius, Jakarta : Listafariska Putra, 2000

Munjid, Beirut :Maktabah al-Syarkiyah, 1986 
Noeng Muhajir, Imu Pendidikan dan Perubahan Sosial : Suatu Teori Pendidikan, edisi IV Yogyakarta : Rake Sarasin, 1993

Oteng Sutisna, Administrasi Pendidikan Dasar Teoristis untuk Praktek Profesional, Bandung: Angkasa, 1983

Pujosuwarno Sayekti, Makna Integrasi Antaranggota Keluarga Dipandang dari Sudut Konseling Keluarga, seri disertasi, PPS IKIP Bandung, 1991

Sayid Nasir Hasyemi, Peran Kasih Sayang dalam Pendidikan, http://www.taghrib .ir $/$ indonesia $/$ index.php?option $=$ com_content\&view $=$ article\&id $=$ 151:peran-kas ih- sayang-dalam-pendidikan\&catid=35:1388-06-2107-28-12\&Itemid $=54$

Syaiful Bachri Djamrah dan Aswan Zain, Strategi Belajar Mengajar, Jakarta, PT. Rineka Cipta, 1997

Syed Hosssein Nasr, Islam Tradisi di Tengah Kancab Dunia Modern, alih bahasa Luqman Hakim, Bandung : Pustaka, 1987

Umar Hasyim, Cara Mendidik Anak dalam Islam, Surabaya : Bina Ilmu, 1985

\section{Artikel}

Afeksi (Kasih SAyang),Wikipedia Ensiklopedia Bebas Bahasa Indonesia, http://id.wikipedia .org/wiki/afeksi

${ }^{1} 7$ Prinsip Pendidikan Tanpa Kekerasan, http:/ /www. wikimu .com/ News /Display

News.aspx?id $=14997$

Rahmah (Kasih sayang), http://www.psq .or.id /ensiklo pedia _detai 1 .asp? mnid $=34 \& i d=107$

Pendekatan dalam Pendidikan Islam, http://ululazmi-zabaz.blogspot .com/2011/03/pendekatan-dalam-pendidikan-islam_25.html

Pendekatan-pendekatan Teori Pendidikan, http://elearning. unesa.ac.id /tag/contoh-makalah-pendekatan-dalam-teori-pendidikan

Wojowasito dan W.J.S Poerwadarminta, Kamus Lengkap Inggeris-Indonesia, Indonesia-Inggris Bandung : Media IPTEK, 2007

Wikipedia Bahasa Indonesia,Ensiklopedia Bebas, http ://id.wikipedia.org/wiki/prinsip 